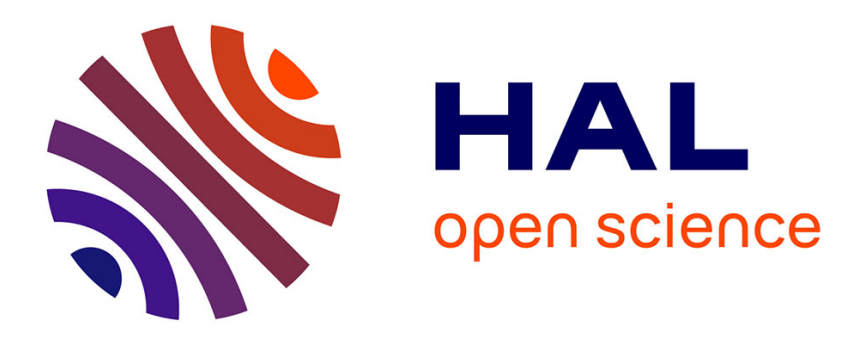

\title{
Sources of Dependence and Strategies to Innovate: Evidence from Video Game SMEs
}

Romain Gandia, Elodie Gardet

\section{To cite this version:}

Romain Gandia, Elodie Gardet. Sources of Dependence and Strategies to Innovate: Evidence from Video Game SMEs. Journal of Small Business Management, In press, 10.1111/jsbm.12339 . hal01696250

\section{HAL Id: hal-01696250 \\ https://hal.univ-smb.fr/hal-01696250}

Submitted on 30 Jan 2018

HAL is a multi-disciplinary open access archive for the deposit and dissemination of scientific research documents, whether they are published or not. The documents may come from teaching and research institutions in France or abroad, or from public or private research centers.
L'archive ouverte pluridisciplinaire HAL, est destinée au dépôt et à la diffusion de documents scientifiques de niveau recherche, publiés ou non, émanant des établissements d'enseignement et de recherche français ou étrangers, des laboratoires publics ou privés. 


\title{
Sources of Dependence and Strategies to Innovate: Evidence from Video Game SMEs
}

\author{
Romain GANDIA \\ Assistant professor \\ Univ. Savoie Mont Blanc / IREGE \\ BP 80439 - 74944 Annecy-le-Vieux \\ romain.gandia@univ-smb.fr \\ Elodie GARDET \\ Assistant professor \\ Univ. Savoie Mont Blanc / IREGE \\ Université de Savoie \\ BP 80439 - 74944 Annecy-le-Vieux \\ elodie.gardet@univ-savoie.fr
}

Recent studies call for reconsideration of the predictions of resource dependence theory, in light of contemporary industrial and economic environments. This study accordingly investigates the influence of dependence on the strategic choice to innovate by focusing on a rarely studied topic, namely, the sources of dependence. In studying small and medium-sized video game enterprises, this article provides empirical validation of dependence phenomena. These companies have limited resources, which inevitably creates dependence, exacerbated in innovative contexts because of the prevalence of negative effects, such as opportunism, abuse of power, limited innovation, or inequitable distributions of economic value. To deal with these negative effects, some enterprises use cooperation or integration strategies to try to minimize their dependence. The strategic choice then might be conditioned. The results of a comparative and qualitative study of five video game developers show that a lack of resources and skills is the primary source of dependence. In addition, a hierarchy of sources of dependence seems to guide the strategic choices of developers to innovate. 


\section{Introduction}

Resource dependence theory (RDT) (Pfeffer and Salancik, 1978) has attracted renewed interest among management science researchers, especially as the digital revolution and emergence of information technologies continue to revolutionize industries and interorganizational relationships (Davis and Cobb, 2010). Despite the explanatory strength of the RDT, many authors also note its limitations (e.g., Davis and Cobb, 2010; Drees and Heugens 2013, Wry et al., 2013), including a lack of empirical validation, predominant focus on larger enterprises, the need to identify new strategies to manage dependency, and the need to update sources of dependence and power. However, the link between sources of dependence and their effects on firms' strategic behavior remains unexplored. Moreover, the specific case of small and medium-sized enterprises (SMEs) continues to be largely ignored, despite the importance of dependence to such firms, considering their small size and limited resources (Wolff and Pett, 2006).

Noting these developments and gaps, we study how sources of dependence affect SMEs' strategy implementations, particularly in innovation contexts. Innovative firms are conducive to the study of phenomena pertaining to dependence, because few SMEs possess all the resources they need to innovate. We focus especially on new product development (product innovation) that imply for SMEs to conduct an innovation process by mobilizing many different types of resources and competencies, often owned by several partners (Dhanaraj, and Parkhe 2006). Therefore, an integration or cooperation strategy is a likely means that innovative SMEs adopt to access missing resources in order to develop a new product (Wang and Zajac, 2007). Yet even research that analyzes the advantages and disadvantages of these strategies (e.g., Balakrishnan and Koza, 1993) offers only a limited understanding of the drivers of a strategy choice to innovate. According to the RDT, strategy provides a lever to control the level of dependence, but we lack insights into the inverse 
relationship, in which the strategy reflects the degree of dependence (Davis and Cobb, 2010). When research investigates external and internal sources of dependence that might affect strategy (e.g., Casciaro and Piskorski, 2005; Xia and Li, 2013), it mostly focuses on mergers, acquisitions, or divestitures, rather than strategies to innovate. We posit that innovative SMEs' strategic choices also depend on the types of resources they need to acquire, such that they may develop innovation networks to access missing resources, whether financial, technical, or technological (Gardet and Fraiha, 2012).

In the video game industry, developers are innovative SMEs because they focus on product development and sometimes on the development of new games (product innovation) for their own ambition. This last situation is interesting to study with a dependence point of view because developers confront a dual dependency: upstream on console manufacturers and downstream on video game publishers (Johns, 2006). Such dependence enables other, more dominant firms to impose their choices and maintain more power (Emerson, 1962), which implies that developers have limited capacity to create value ${ }^{1}$ and innovate. Because value capture $^{2}$ depends on the power relationships among stakeholders (Bowman and Ambrosini, 2000), dependent developers capture only a small share of the value generated by the sale of innovative video games. To overcome these negative outcomes, developers might try to minimize their dependence, using either integration or cooperation strategies. This strategic choice also may be conditional; depending on the level and type of resources owned by developers, the type and level of missing resources differs. From this perspective, we assess how the nature of the sources of dependence influences the strategic choice to innovate. That is, how do sources of dependence influence the strategic choices that SMEs adopt in their efforts to innovate?

\footnotetext{
${ }^{1}$ Value creation refers to the invention or reconfiguration of assets and skills in a way that makes it possible to create usage value (e.g., new product, new service), subjectively perceived as new and relevant for the potential user (Lepak et al., 2007).

${ }^{2}$ Value capture is the capacity of the firm to capture material (monetary) or immaterial (knowledge, reputation) value, in exchange for the usage value created for the potential user (Lepak et al., 2007).
} 
To answer this question, we first identify several internal and external sources of dependence and strategies that SMEs use to innovate when they face a situation of dependence. Next, we detail the characteristics of the video game industry, our data collection method, and five case studies. After we present the results and note the link between the source of dependence and strategic choices, we conclude with some limitations and suggestions for further research.

\section{Sources of Dependence and Strategies to Innovate}

Resource dependency theory states that organizations act in ways associated with their level of dependence upon various resources (Pfeffer and Salancik, 1978). Organizations act upon their environments in attempts to reduce dependency on certain resources and to maintain independence over other resources. RDT states that the degree of interdependence and the nature of interactions among functional specialists within an organization are influenced by the nature of the collective task they seek to accomplish (Swink and Zeng, 2000). Video game development involves many different specialists. Each is highly dependent on others for information necessary to complete its objective. RDT states that the power of an organization (in the paper the video game SME) depends upon the resource dependency relationships it has with other organizations. If a video game SME is highly dependent upon another organization for an important, that other organization of the value chain will have power over the SME. “RDT was originally formulated to discuss relationships between organizations” (Medcof, 2001, p. 1002) and that is what we try to do in this paper with a special focus on video games SME and the consequences on strategic choices to innovate.

The revival of interest in RDT in management science (David and Cobb, 2010; Pfeffer and Salancik, 1978) seemingly has arisen because shifts in economic and industrial contexts provide interesting empirical settings for its investigation using new alternatives (Gulati and 
Stych, 2007). Yet aspects of the theory remain underexplored, particularly with regard to the identification of sources of dependence and their relation to strategy (Davis and Cobb, 2010). To the best of our knowledge, no previous study considers both internal and external sources of dependence within a SME, apparently for two main reasons: (1) a dominant focus on large firms and (2) a concentration on internal and external conditions of dependency and their consequences, rather than their sources. Prior literature attends closely to large companies, because in such settings, the study of resource dependence is easier and entails multiple applications $^{3}$ (Davis and Cobb, 2010). We also note some research that addresses the internal and external conditions of dependency in large firms or industries (Bahli and Rivard, 2003; Casciaro and Piskorski, 2003; Xia and Li, 2013), but again these studies ignore dependence sources and SMEs. In research that deals with SMEs (e.g., Adams et al., 2012; Diez-Vial, 2009; Voss and Brettle, 2013), the focus is on the link between resource dependence and strategy, rather than sources of dependence or strategies to innovate. In this context, a typology of resources might be beneficial for identifying sources of dependence. First, according to RDT, dependence results largely from a lack of resources: ${ }^{4}$ Depending on the criticality and substitutability of the resource, a SME may be more or less dependent on its stakeholders (Pfeffer and Salancik, 1978). Conversely, controlling critical resources confers a high level of power over companies that covet these resources (Nienhüser, 2008; Tan et al., 2008). The resource concept thus is central to studies of dependence and should provide a means to identify the sources of this phenomenon. Second, Pfeffer and Salancik (1978) argue that the need for resources and transactions can explain the strategic choices of firms, such that to control or modify their environments, firms establish clear strategies. But their analysis

\footnotetext{
${ }^{3}$ Such applications include the role of technology (e.g., Dunford, 1987; Katila et al., 2008), how dependence affects internationalization strategies (e.g., Gaffney et al., 2013), merger and acquisition settings (e.g., Casciaro and Piskorski, 2005; Finklestein 1997; Xia and Li, 2013), network strategies (e.g., Gulati, 2007; Westphal et al., 2006), and the performance and composition of boards (e.g., Hillman, 2005; Hillman et al., 2007).

${ }^{4}$ We use "resource" not in the strict sense of the resource-based view (Teece, 1982) but rather more broadly (Lavie, 2006). The lack of resources is not the only way to identify sources of dependence, but it provides a starting point for our research.
} 
only applies to the firm's goal of reducing the degree of dependence; it ignores the influence of dependence (and its sources) on the strategic choice to innovate. This gap is notable, because innovation is crucial to firm survival and growth (Baumol, 2002). When firms, especially SMEs, lack the internal resources needed to innovate, which implies a situation of dependency, they might adopt either cooperation or integration strategies (Shuang-yan et al., 2013; Wang and Zajac, 2007). It seems likely that there is some link between the sources of dependence and the strategic choices to innovate.

\section{Internal Sources of Dependence}

Internal dependence mainly arises from a lack of resources or skills (Lavie, 2006). Following a substantial research tradition (Barney, 1991; Chatterjee and Wernerfelt, 1991; Hall, 1992, 1993; Teece, 1982; Wright et al., 1993), we consider two broad classes of resources: (1) tangible, comprising financial, physical, and human resources, and (2) intangible, including technical and reputational resource. A firm embodies multiple financial, physical, and human resources, which must be durable and specific if they are to support the firm's competitive advantage. Financial resources consist of internal funds (e.g., liquidity, capital, cash flow, profit level, debt capacity to borrow) and external funds (e.g., new equity, subvention, high-risk debts, customer credit). Physical resources entail fixed capacity, such as plants, industrial equipment, raw materials, product, stock, property, and stores. Often characterized as valuable, rare, inimitable, and non-substitutable, human resources comprise individual knowledge and skills, the abilities of different employee categories in the firm (e.g., creative people, operators, managers, directors), the remuneration system, recruitment, training, and communication. Technical resources pertain to the exploitation of organizational, technological, and relational capital to develop brand equity, including intellectual property rights, patent portfolios, manuals, procedures, and copyrights. Finally, reputational resources are specific and intangible, determined by the levels of the firm's 
reliability, market share, loyalty, perceived product quality, and brands, according to other actors in a market, value chain, or industry. The SME must find internal or external resources that it can acquire, exploit, and combine to support its strategic purposes (Gulati, 2007). With this study, we aim not to offer an exhaustive categorization of various types of resources and skills but rather to analyze their influences on degrees of dependence. We thus consider general resource types (as derived from Barney, 1991; Chatterjee and Wernerfelt, 1991; Hall, 1992, 1993; Lavie, 2006; Teece, 1982, Wright et al., 1993).

Resources held internally determine the level of dependence of an actor and thus its level of power (Emerson, 1962). This point is important, because our analysis focuses on asymmetric but complementary relations in which the actors aim to access the resources held by their partners (Hamel and Prahalad, 1994).

Size is another possible source of dependence, because it can determine the level of power that derives from the internal resources held by the firm (Pfeffer and Salancik, 1978). A large firm usually has more power in its industry (Oliver, 1990), particularly in negotiations; SMEs, which usually specialize in limited activities in the value chain, have less bargaining power and must depend on providers and clients (Diez-Vial, 2009). A SME’s interactions with other firms thus tend to be strategic, which can create an initial imbalance in bargaining power (Gardet and Mothe, 2011).

\section{External Sources of Dependence}

Prior literature highlights two main external sources of dependence: the nature of technology (support) and position within the industrial sector. First, technology support has a significant impact on relationships within an industrial sector (Stieglitz and Heine, 2007). When a firm has a specific technical capability that is necessary for product development, its bargaining position is stronger (Kumar and Van Dissel, 1996). Thus, technology influences 
the degree of interdependence between firms, and downstream actors likely are obliged to exploit the existing technology standard to create and distribute products.

Second, with regard to firms' positions in the industrial sector, we distinguish two situations: upstream, such that firms innovate, or downstream, such that firms commercialize and distribute innovations in the market and capture most of the economic returns. To create products for customers, upstream firms must cooperate with downstream firms, which grant the downstream firms greater bargaining power due to their control of access to the market. Other influences on bargaining power between downstream and upstream firms include sales density (Burt and Sparks, 2003) and the degree of concentration; in more oligopolistic markets, the risk of dependence increases (Miles et al., 1999; Nooteboom et al., 2000).

These various sources (resources, skills, firm size, technology, position) determine the degree of firm dependence within a sector, as well as its bargaining power, which in turn affects negotiation power and value sharing. More dependent firms may try to implement strategies to reduce their dependence so that they may capture more value. In addition, their strategic choices (cooperation or integration) may be influenced even further by the specific sources of their dependence.

\section{Strategies to innovate for Dependent SMEs}

Few SMEs can control all the resources they need to innovate, so dependency between firms is almost invariable. To innovate, SMEs might access additional resources in various ways, such as internalizing a source that already possesses a needed resource or building the competency to generate that resource themselves (Gulati, 2007; Vossen, 1998). In addition, they can enter into cooperative arrangements with another firm that has access to the resource in question (Fink and Kessler, 2010). In this study we consider only strategies implemented by the firm to support the product innovation, in a situation of new product development. 
Thus we are focused on two types of strategies to innovate: cooperation or integration of resources and skills (Wang and Zajac, 2007).

In an innovation perspective, a cooperation strategy implies that independent SMEs come together in a common project for an extended duration. This is the case of a project of new product development. With such a strategy to innovate, SMEs gain access to their partners' skills and enjoy lower costs, risks, and competition (Fink and Kessler, 2010; Hagedoorn, 1993). The cooperation might feature a competitor or an upstream or downstream partner (Wang and Zajac, 2007). A downstream firm offers greater proximity to the market and a good understanding of the needs and expectations of final customers (Mohr and Spekman, 1994). In contrast, upstream firms provide technology access, and competitors support more diversified offers for customers and generate greater bargaining power to deal with upstream and downstream firms (Hagedoorn, 1993), especially for SMEs (Fink and Kessler, 2010). Although cooperation thus can provide access to financial, technical, and human resources, it also invokes high coordination costs. In addition, the partners must achieve a sufficient level of trust to avoid the threat of opportunistic behavior (Hamel et al., 1989). Cooperation derives from a combination of organizational partners and industryrelated motives. According to RDT, certain resources can drive a firm to adopt a cooperation strategy. As Katila et al. (2008) explain, when a company has high demand for financial and managerial resources, it tends to enter into investment relations with other stakeholders through collaboration. Gulati (2007) also notes that the need for access to external resources leads to alliance development; these solutions effectively benefit companies that lack the means to implement an integration strategy. However, prior studies do not analyze various missing resources as sources of dependence, nor do they focus on SMEs or innovation.

Some SMEs adopt an integration strategy to innovate and develop a new product, which consists of three general forms: employee training, recruitment, and firm acquisition. An 
integration strategy allows SMEs to retain and increase control over the activities of the innovation process ${ }^{5}$ and offers more protection for the innovation outcomes and high-value assets (Pisano and Teece, 2007; Shuang-yan et al., 2013; Teece, 1986), while also reducing the threat of opportunistic behavior. However, integration is often more expensive than cooperation, despite the reduced transaction costs and increased income (Wang and Zajac, 2007). Furthermore, in the case of an acquisition, conflicts surrounding organizational specificities, such as leadership, culture, technology, management, and communication, often arise (Busija et al., 1997). For SMEs, Diez-Vial (2009) shows that firm size influences the decision to use a vertical integration strategy to reduce dependence on suppliers or external customers. That is, when SMEs have difficulty assessing the benefits of resources available in a transaction, they prefer to avoid vertical integration, which leads to a loss of flexibility and specialization (i.e., their competitive advantage) and requires too many changes. Large firms instead prefer vertical integration, to exploit their capabilities throughout the value chain (Diez-Vial, 2009). Regarding sources and outcomes of dependence other than size, Casciaro and Piskorski (2005) show that a high level of mutual dependence drives merger strategies between public firms, whereas power imbalances preclude this strategy. Similarly, Xia and Li (2013) explain that high mutual dependence between a public holding company and its subunits lowers the chances of divestment of any subunit. A strategic alliance between the subunit and a competitor also can increase the power of the subunit and decrease the likelihood of its divestment. Although these studies reveal that sources of dependence can influence strategic choices, they assess merger strategies by public firms, without detailing different resources, and thus cannot specify the sources of dependence.

Finally, integration and cooperation may lead to different ways to innovate. Therefore, the SME's choice likely depends on both its motivations (e.g., internal control, resource

\footnotetext{
5 Activities of the innovation process traditionally refer to creativity, research and development, conception, production, commercialization and diffusion - including the development of technological assets and networking ability with partners both inside and outside the value chain and value network (Chesbrough et al., 2006).
} 
requirements, external opportunities) and its environment (Gulati et al., 2012; Timmer et al., 2013; Zhang et al., 2010). Although cooperation appears more appropriate in many cases because it allows increasing the innovation potential and the development of new products (Chesbrough et al., 2006), it is not always possible. The SME's initial position within its industrial sector and current level of resources might not offer sufficient attraction to a partner, so its strategic choice would be imposed on it. In Figure 1, we summarize this discussion in a proposed conceptual framework for our empirical study.

In line with prior research (Casciaro and Piskorski, 2005; Wang and Zajac, 2007; Xia and $\mathrm{Li}, 2013$ ), we focus on the link between sources of dependence and strategic choices to support innovation. Research in the RDT tradition indicates that the higher the level of internal resources, the lower the level of dependence. Therefore, when the firm possesses more internal resources, it should be more likely to pursue an integration strategy. If the SME has few internal resources, it likely adopts a cooperation strategy. No literature predicts the link between various sources of dependence and cooperation or integration strategies. That is, despite the importance of SMEs' dependence, we lack a detailed, granular account of how sources of dependence influence strategic choices to innovate.

\section{INSERT / Figure 1: Conceptual Framework}

\section{Methods}

The multiple case research design supports a replication logic, such that the cases represent a series of experiments that confirm or disconfirm the emerging conceptual insights. Emergent theory from multiple case research tends to be more generalizable and better grounded than theory from single case studies, making it more amenable to extension and validation with other methods (Davis and Eisenhardt, 2011). 


\section{Research Setting}

With video games as our research setting, we investigate a creative industry. Creative industries have unique traits, compared with traditional industries (Greenman, 2012). The video game industry is highly innovative and characterized by heightened competition, in which heterogeneous firms are differentially subject to dependence (Johns, 2006). In traditional, platform-based video game markets, the different actors specialize in particular phases of the process of creating and developing video games (Tschang, 2007). This specialization largely determines dependence (Johns, 2006). The manufacturers (Sony, Microsoft, Nintendo) create and distribute technology and platforms (consoles); developers (innovative SMEs) develop new and revised games; publishers (large local and multinational firms) finance and promote the games; and distributors (large, generally multinational firms) provide access to wholesalers and retailers. Our study focuses on developers (innovative SMEs) and especially on new product development when the developer want to make a new original game of its own choosing and not in response to a publisher demand. In this situation, they are the most dependent actors on the market for console games and this explain our second focus on this specific market segment. Upstream, they depend on manufacturers to gain access to technology standards (Tschang, 2007). Downstream, they depend directly on publishers to access financing and marketing arrangements and indirectly on distributors to reach distribution networks (Johns, 2006).

From a RDT perspective too, developers are interesting to study, because these innovative SMEs confront varied sources of dependence that can influence their strategic choices. For innovation projects, they must create a completely new game, new technical interface (e.g., game engine, graphics), or new editorial point view (new intellectual property) (Tschang, 2007). Thus, innovation can takes place on three levels (Aoyoma and Izushi, 2003; Gallagher and Ho Park, 2002; Tschang, 2007): (1) on the product level, when the product 
created is really new (new concept of game based on an innovative gameplay or a really original story) and very different of existing games on the market, (2) on the technology level, when the developer create a new game engine using for graphic game capabilities) and (3) on the organizational level, when the developer adopt an original model for organizing the process of development. This requires substantial financial resources and technical skills (Cohendet and Simon, 2007), which forces SMEs to cooperate with other actors (especially publishers and distributors) thus creating dependency relationships and potential negative effects on the activities of the innovation process (Johns, 2006). These dependency relationships are based on the exchange of several critical resources: (1) financial resources, (2) marketing resources for commercialization and promotion, (3) distribution resources. In the relation with a publisher and a distributor, these missing resources can strongly impact the internal resources of the developer (Idem, 2006). Financial resources generally influence technical resources and the organization of human resources because developers must collaborate with a publisher to obtain the funding required for the game development. In this way, the publisher has a strong power toward the developer and can impose several technical and artistic choice (Tschang, 2007). These constraints can imply a transfer of intellectual property (transfer of technical resources) and can modify the organization of teams during the process of development. The developer's size can be also influenced by the publisher because this last can impose some own human resources that will participate and control the innovation process. Marketing and distribution resources can influence the reputation because the publisher (with the transfer of the intellectual property) will communicate about the game in his name and not in the name of the developer. In this way, the developer has difficulties to build its reputation and its position in the industrial sector can also evolve with difficulties.

The analysis of the video game industry, using the lenses of developers and innovation projects, is relevant for three main reasons. First, an analysis of the impact of the sources of 
dependence on the strategic choice to innovate can address the limitations of RDT (Drees and Heugens, 2013) and help update RDT predictions by integrating contemporary and empirical analyses of the sources of dependence to explain external control over SMEs (Voss and Brettle, 2013), as requested by Davis and Cobb (2010). Second, our focus on innovative projects contributes to research on strategies to innovate (Gulati and Stych, 2009) and innovation networks (Gardet and Fraiha, 2012); the analysis of sources of dependence helps explain external controls over innovation activity and SMEs' strategic choices. Third, by addressing the strategic behavior of developers, this study can help SME managers understand the origin of their resource dependence, anticipate its consequences, and guide the strategic choice to innovate to overcome the constraints they face.

\section{Case selection}

Researchers call for rigorous case studies of the concept of dependence and its application by SMEs (Adams et al., 2012; Diez-Vial, 2009; Gardet and Fraiha, 2012). In this study, we conducted case analyses of five SMEs that act as developers in the video game industry and are particularly subject to dependence. These developers vary in size (12-500 employees) and their level of internal resources (low-high), such that they offer sufficient distinction to support meaningful comparisons and enable us to control for idiosyncratic influences. They also exhibit some similar characteristics, such as their knowledge of video game development and their interactions with the international gaming market and large multinational partners, including manufacturers, publishers, and distributors. We thus consider a fairly consistent representation of the different levels of dependence (higher or lower) that innovative SMEs face and the different types of resources they have or need to acquire to innovate. We use pseudonyms for all the companies to ensure confidentiality (detailed descriptions are available on request). The five developers include four French SMEs: Flashgame, Evolugame, Jemulex, and MOP, as well as Creagame, which is a 
Canadian firm. Flashgame, Evolugame, and Jemulex are local businesses; Creagame and MOP are global companies with other developers in the video game and related industries (e.g., animation, publishing, Internet). Table 1 summarizes their key characteristics.

\section{INSERT / Table 1: Major characteristics of the five SME developers}

\section{Data Collection}

The data collection, which took place between September 2009 and October 2010, included several data sources: (1) interviews, (2) internal data and corporate material, and (3) external data including media and websites. We employed several data collection methods to exploit the synergistic effects of combining them through triangulation (see Table 2).

\section{INSERT / Table 2: Primary and secondary data collected for the five SME Developers}

The main primary data source was semi-structured interviews with SME directors who make strategic choices and employees representing different functions (e.g., technological, creative, R\&D) who have a good knowledge of the firms' strengths and weaknesses. We conducted 18 semi-structured interviews with video game developers. Each interview was 60-90 minutes long, taped, and transcribed. For each interview, we constructed an interview guide, structured around four steps. First, we asked respondents to tell the story of their developer, so that we could acquire historical knowledge of the developer and its business specialization, strategic positioning, internal resources and skills, internal organization, and strategic development over time. With this information, we determined why the developer experienced a situation of dependence. Second, we discussed the relation between the developer and the other firms in the industry. Our objective was to get a clear view of the developer's environment and professional network, to identify the main elements of its dependence. Third, we discussed dependence in detail, using semi-structured questions and guidelines to identify specific sources. Fourth, we finally focused the interview on strategies to innovate, in an effort to understand how sources of dependence shape strategic choices. 
We also consulted internal sources, including 8 contracts, 19 project documents, 36 emails, and 16 statistical reports. These items provided a better understanding of the relationship between SMEs and other actors in the innovation project. Project documentation and emails were particularly useful in revealing the power of external actors and the role of owned or missing resources for advancing the innovation project. We thus sought to understand the overall structure of the project.

Consistent with our multiple case research strategy, the data collection incorporated external data too. We studied 6 websites hosted by the developers and 32 digital journal articles from popular video game industry publications. Through this investigation, we gained background information about the developers (e.g., history since their creation, reputation, business specialization, network collaboration, video games created, internal staff, turnover), as well as accurate, external information about the innovative game they had produced through their development projects.

To address the potential for informant bias, we triangulated these data from multiple sources and ensured that we asked open-ended questions regarding the knowledgeable informants' relations with other firms in the value chain. We also promised anonymity to the informants and their firms. With "courtroom questions," we focused on factual accounts of what informants did or observed others doing (e.g., technology used, size of the firm, internal resources possessed, partners) and avoided speculation (Hallen and Eisenhardt, 2012). The SMEs directors in particular should have been very motivated to be accurate, because they were very interested in learning how their sources of dependence might limit their innovation activities and discover ways to adapt with a specific strategy.

\section{Data Coding and Analysis}

To code the data from different sources, we used typical content analysis procedures (Miles and Huberman, 2003). We coded all data into categories, according to our proposed 
theoretical model (Yin, 1994). The data analysis followed identical steps for each of the five video game developers and each type of data. We conducted thematic coding by crossing our obtained data with findings from prior literature and thereby developed a dictionary of topics. Table 3 provides examples of our data coding procedure.

\section{INSERT / Table 3: Examples of Data Coding}

For the codification of these themes, we manually classified the data into two broad categories: developers' sources of dependence and strategies to innovate. For the former, we identified, from both prior literature and the cases, different types of internal (financial, material, human, technical, size, reputation) and external (technology support, position in the industry) resources. We assigned a code to each dimension (e.g., DEP_FINANCE for financial resources). For the latter, we again referred to extant literature and our cases and created three themes: cooperation, integration, and lack of strategy. Codes reflecting the level of intensity enabled us to differentiate sources of strong $(+++)$, medium $(++)$, weak $(+)$, or no (-) dependence. To estimate the level of intensity, we compared the level of internal mastery of the developer against its level of missing resources.

\section{Dependence of SME Video Game Developers}

We present our case study results in three stages: (1) the key role of resources and skills compared with other sources of dependence, (2) how these sources of dependence influence the strategic choice to innovate, and (3) the relationship between the source and the strategic choice.

\section{Main Sources of Dependence of Creative SMEs}

Because of their position, video game developers experience a high degree of dependence, which arises from multiple sources. For our five cases, we classified the different sources of dependence according to their strategic importance to the developer and found that 
a lack of financial resources was the primary source. That is, the creation of a new video game requires significant financial investments, which most developers cannot support alone. This form of dependence mainly emerged from relations with downstream firms (publishers and distributors), with two negative consequences. First, it established editorial dependency. With their greater bargaining power, publishers imposed editorial restrictions on the developers, which limited their creative freedom. Second, it was intimately related to intellectual property right (IPR) transfers, another important source of dependence. When a publisher finances the entire development of a video game, the developer must transfer all its IPR. Other sources of dependence, such as the nature of the technology, pertained mostly to upstream firms, such as manufacturers and middleware suppliers, whose technology standards define how the developers can create games. Finally, firm size, position in the industrial sector, and reputation appear to have less importance, as we summarize in Table 4.

INSERT / Table 4: Main Sources of Dependence of Creative SMEs

\section{Influences of Sources of Dependence on Strategic Choices to Innovate}

The SMEs in our study chose to cooperate in their innovation activities only with competitors. That is, we observed no examples of cooperation with an upstream or downstream partners. ${ }^{6}$ Upstream, three console manufacturers share the market (Nintendo, Sony, and Microsoft), and technology costs create high entry barriers. Downstream, despite the potential benefits of innovating with publishers, this situation has not arisen, perhaps because an exclusive relationship with a single publisher could increase the level of dependence even further. Thus, both cases of cooperation (Flashgame and Evolugame) involved competitors, and the pertinent sources of dependence in these cases were a lack of financial resources, transfer of IPR, and a lack of reputation. This finding seems reasonable; these three sources are intimately related, in that the funding from a publisher prompts the

\footnotetext{
${ }^{6}$ Firms are limited to supplier relations.
} 
transfer of IPR, which then limits the developer's visibility. ${ }^{7}$ Although cooperation with a competitor could involve pooled financial resources, in which case the developer might retain some IPR, the economic returns captured are proportional to the investment made. For Flashgame for example, the profit sharing was unequal because of the significant investments by its partners (15\% Flashgame, 35\% developer partner, 50\% publisher). For Evolugame, the sharing was more equitable (30\% Evolugame, 30\% developer partner, 40\% publisher).

The other three SME (Creagame, Jemulex, MOP) instead adopted integration strategies focused on financial (due to the success of their previous video games), human, and technical (supporting development and distribution) resources and skills. By gaining competency with different types of technologies, these developers shifted their positions in the industrial sector. However, no integration of resources appeared in markets for game consoles, ${ }^{8}$ probably due to the lack of financial resources, nature of the technological support, and position within the industrial sector. Jemulex suffered an unfavorable position in its industrial sector, which led it to internalize new resources by training employees, with the objective of controlling the distribution of its product by creating websites. In contrast, MOP already was controlled by downstream activities in its industrial sector, so the binding nature of the technology mostly influenced its choice; it hired employees with suitable technical skills to address manufacturers' standards. Finally, the strategic choice made by Creagame reflected its lack of financial resources, technical considerations, and unfavorable position. Faced with these multiple sources of dependence, it invested in human and technical resources to address manufacturers' standards and control online distribution. Both MOP and Creagame favored the integration of upstream resources and skills; Jemulex instead integrated downstream

\footnotetext{
${ }^{7}$ For a developer, the retention of IPR is a way to remain visible to other firms in the industry.

${ }^{8}$ A developer would need extremely high financial capacities to integrate the business of a manufacturer, publisher, or distributor. The only example we know is Ubisoft, which was not one of our case firms.
} 
resources and skills. We summarize the sources of dependence and their influence on strategic choices by the five developers ${ }^{9}$ in Table 5 .

INSERT / Table 5: Sources of Dependency and Influences on Strategic Choices to

\section{Innovate}

\section{Discussion}

Although only a minor source of dependence, size might have an important influence (Gardet and Mothe, 2011). For example, in our cases, size is important in relation to the commercialization of tangible products (consoles and PC), such as for Flashgame, which cooperated with a larger developer. The competitive interdependence situation (Casciaro and Piskorski, 2005) and size differences imply asymmetries of dependence (Gulati and Stych, 2007), which only affect the symbiotic dependence of Flashgame on its publisher. When developers create products in dematerialized markets (e.g., Internet), size does not matter. For example, Jemulex used the Internet to access customers directly, eliminating the need for a distributor.

Our results also indicate that an integration strategy is more common than cooperation; in three of our five cases, the developers favored the integration of resources and skills. We acknowledge that it is difficult to generalize from these findings, considering the limited number of cases. However, despite the additional costs and decreased flexibility associated with integration, developers prefer it, perhaps because they retain editorial freedom, which is extremely important as the core of artistic creation. Because artistic creation leads to the creation of value, such freedom may be an important source of these creative SMEs' profit (Bowman and Ambrosini, 2000), as well as their primary motivation (Storz, 2008). In contrast, in non-creative industries, financial returns are often the primary motivation. In these industries, cooperation offers access to new resources and skills, allows the SME to focus on its core business, and provides economies of scale (Fink and Kessler, 2010; Stieglitz and

\footnotetext{
9 We categorize SMEs according to their integration or cooperation strategies to determine their lack of resources. However, we do not investigate the dyadic relation between developers and publishers.
} 
Heine, 2007), whereas integration might imply organizational rigidity and a lack of reactivity in turbulent environments (Villalonga and McGahan, 2005). Our case studies suggest the video game industry reverses these effects, for three main reasons. First, the extreme heterogeneity of corporate cultures in this industry tends to increase coordination costs. Second, its added value depends largely on the creativity of developers, which is difficult to measure and allocate in cooperative contracts. Third, creative freedom diminishes when all SMEs must agree on common goals (Hamel et al., 1989).

With regard to the influence of the different sources of dependence on strategies to innovate, we note three key elements. First, none of the developers we studied controls all the resources and skills that would be needed to develop a video game. Prior literature recognizes that some characteristics of resources tend to increase (or decrease) a SME's bargaining power, such as the specificity of its assets, access to resources, level of concentration (Pfeffer and Salancik, 1978), and intrinsic values. Our case studies show that IPR is one of the most important resources, an observation confirmed in other high-tech industries (Chesbrough, 2003). By protecting $I P R,{ }^{10}$ developers can avoid the threats of both imitation and opportunistic behaviors, which can jeopardize their survival and growth (Pisano and Teece, 2007). This protection also ensures a greater capture of economic returns (Chesbrough, 2003). Thus IPR represent a separate resource class and a specific protection mechanism (Chesbrough et al., 2006), as well as strategic resources that confer an intrinsic value to developers, enabling them to develop a competitive advantage and greater bargaining power. Furthermore, RDT helps establish links between the type of resource sought and the degree of dependence, which can lead to two forms of interdependence: symbiotic or competitive (Casciaro and Piskorski, 2005). In the video game industry, symbiotic interdependence is more common, because developers primarily seek vertically connected partners in their

\footnotetext{
${ }^{10}$ This protection takes different forms, such as patents and copyrights (Pisano and Teece, 2007).
} 
industrial sector. However, competitive interdependence appears too, particularly in relationships among developers, such as when Flashgame and Evolugame cooperated with competitors.

Second, the two developers that lost their IPR (Flashgame and Evolugame) used cooperation to pool their financing capabilities and achieve greater bargaining power over publishers. With this tactic, they limited the publisher's investment, retained more IPR, and reduced their levels of dependence. However, if developers already maintain their IPR, they prefer to integrate upstream (Creagame and MOP) or downstream (Jemulex and Creagame) resources and skills. Chesbrough et al. (2006) consider IPR a strategic asset that must be developed, sold, or purchased, but neither Flashgame nor Evolugame followed any of these routes. Instead, they chose cooperation to co-create a video game and shared their IPR. From a complementary resources perspective, the willingness to share IPR suggests a desire to control objective legal resources (contracts, IPR, laws, regulations) and manage IPR practices (Eppinger and Vladova, 2013). Yet neither of these developers had knowledge of the legal status of the video game, or even the laws and legal mechanisms that applied to their industrial sector.

Third, Flashgame and Evolugame lacked notable reputations in the industrial sector. Reputation depends on two elements (Rhee and Valdez, 2009): quality and visibility compared with other firms. If a developer creates a reputation as a quality service provider or partner, it can access more future business opportunities. In the video game industry, visibility depends on the ownership of IPR, which increases developers' creativity and freedom and thereby makes their unique know-how visible. In manufacturing industries in contrast, it is possible to be recognized even without ownership of IPR (Rhee and Valdez, 2009). In creative industries, the ownership of IPR offers intrinsic value to developers and contributes to their reputation. 


\section{Conclusion}

We identified several main sources of dependence and their likely influences on the strategic choice between integration and cooperation for innovation. With five case studies, we have clarified how these sources influence strategies to innovate and provided three main contributions. First, a lack of financial resources leads to the primary source of dependence for developers. Size does not appear as a main dimension, because a small and a large developer can have the same level of dependence. Other dimensions also can decrease dependence, such as IPR or a good reputation. Second, the sources of dependence influence strategic choices about innovation. Most previous research has analyzed the influence of strategic choices on firm performance (Wang and Zajac, 2007); our goal instead was to identify the sources that lead to such choices. From an innovation perspective, internal sources of dependence tend to encourage a cooperation strategy (to overcome the lack of resources and skills), whereas external sources of dependence generally lead to an integration strategy (to increase control over innovation activities and capture more value). Third, a hierarchy of sources of dependence seems to guide the strategic choices of developers. For Flashgame or Evolugame, influenced by all the sources of dependence, the chosen strategy is to retain IPR and build reputations. When a developer retains its rights and is recognized, it also innovates by integrating upstream resources and skills, with the aim of reducing technological dependence (e.g., Creagame, MOP). When dependency can be overcome (Jemulex), the integration of downstream resources seems favored. Thus, decreasing degrees of dependence seem to follow a series of steps: possession of IPR and reputation, then the integration of upstream resources and skills, and finally the integration of downstream resources and skills. This process evokes the notion of path dependency (Storz, 2008), in which firms follow a common evolutionary path. 
Finally, this study is subject to several limitations, which create opportunities for further research. In particular, we did not consider the potential for interdependence among partners. For example, focusing on one type of SME in the video game industry could reveal sources of dependence for other firms too, thereby supporting an analysis of interdependencies and insights into mutual dependence (Casciaro and Piskorski, 2005), to refine our understanding of the strategies implemented by developers. It also would be interesting to consider subunit power as a boundary condition for how the mutual dependence logic applies to integration or divestiture. Xia and Li (2013) show that both mutual dependence and increased subunit power determine subunit divestiture; additional research could examine how mutual dependence and increased subunit power simultaneously or jointly affect strategic choices in the video game industry. Whereas we collected data from single informants and neglected other firms in the dyad or market, ongoing research could collect insights from multiple cooperative actors to assess the effects of their interdependence. In addition, our case studies include only SMEs, in which the company manager has an essential role (Chollet et al., 2014). Thus the manager's personality could have a strong impact on a SME's strategic choices; a risk-averse company manager probably prioritizes the safety of the asymmetrical relationship rather than editorial freedom. In our cases, the company managers wanted to increase SME growth, so they systematically sought to minimize their degrees of dependence. Studying other developers that prioritize safety might provide an interesting extension. Our results indicate that cooperation is more likely when creative SMEs experience high dependence. However, if a SME gradually exhausts its partner’s relevant knowledge, this cooperative spirit may diminish over time. Because the state of cooperation may change, a longitudinal study of the dynamic of cooperation may be warranted (Rindfleisch et al., 2008). From a theoretical perspective, we used a broad conceptualization of resources, as an entry point for identifying sources of dependence. Other resources, especially intangible resources, could be analyzed more 
precisely. We have insisted on the reputation but without dissect its determinants, characteristics nor even considered different kinds of reputation. As part of the reputation, the talent acquisition and management is also a relevant intangible resource that can be key for the developer's reputation in creative industries - and maybe have an influence of the dependence management. Beyond resources, other elements could come into play as well, such as the concentration of actors in the market, the level of power, the country or the size differences. Further research should take into account the role of these elements and study their effects. In addition, our analysis is limited to the relation between sources of dependence and the strategic choice to innovate but without including the effect of the strategic choice on the innovation performance or its success. By knowing that the success of new games developed by certain developers studied was disappointing, it would be interesting to further this work. From a methodological perspective, we selected the video game industry to test our framework, because of the influence of sources of dependence on the strategic choices of firms in this industry. We believe that this specific industry represents most creative industries, but we also acknowledge that the results may differ in other sectors. In addition, our relatively small sample included interviews with knowledgeable respondents, but it is not exhaustive. Because of the confidential and strategic nature of our interview topics, it was challenging to find other developers that would agree to disclose their dependence and strategies. Additional research with a multinational or multilateral framework might pursue a larger sample size and adopt a quantitative methodology.

This study has useful implications for managers of SMEs that face dependence. Before choosing between integration and cooperation, SME managers should evaluate their level of dependence-and more meaningfully, the sources of this dependence. This study offers some guidelines for SME managers, by explaining how a SME can minimize its dependence. In 
particular, the framework provides guidance for more effective management of the degree of dependence experienced by SME developers on other actors in the value chain. 
TABLES AND FIGURES

Figure 1

Conceptual Framework

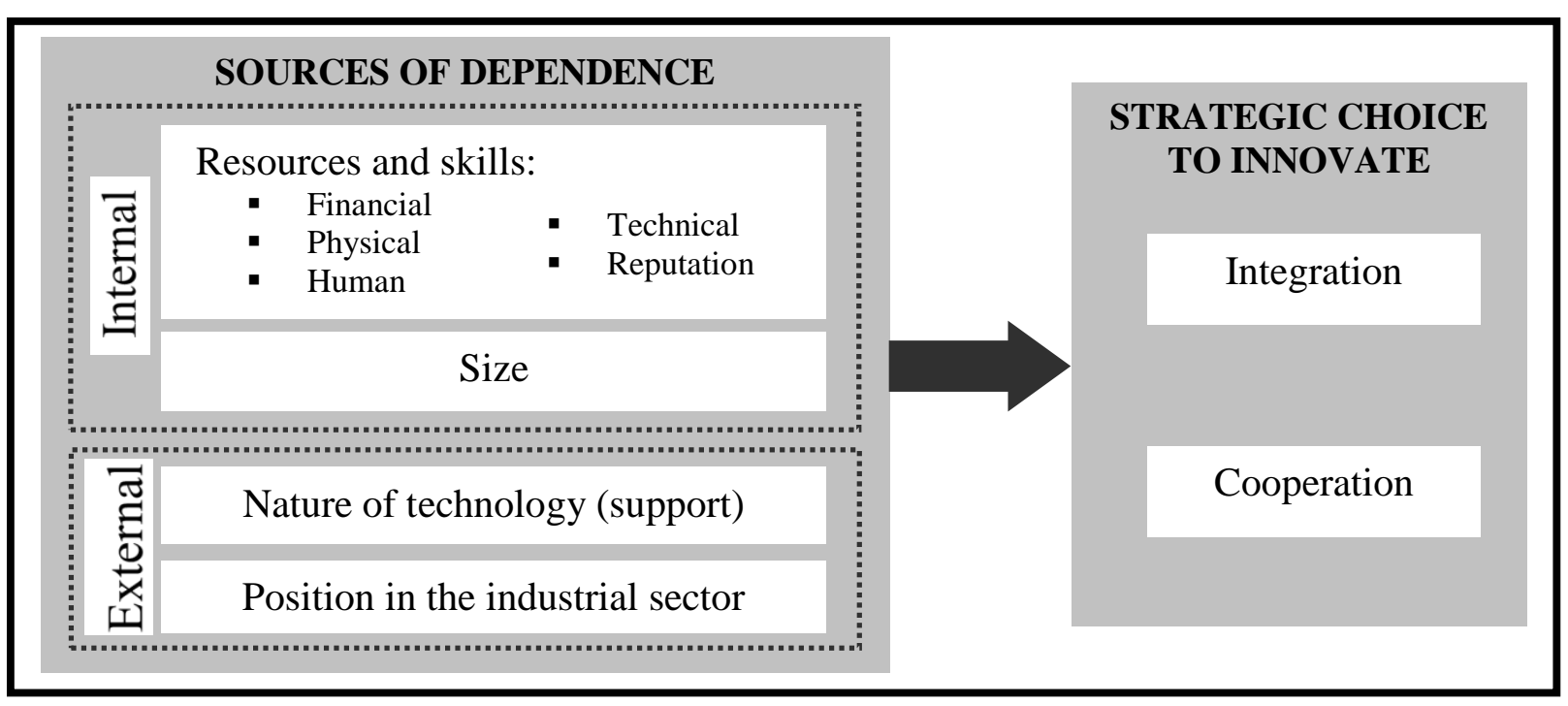


Table 1

Major Characteristics of the Five SME Developers

\begin{tabular}{|c|c|c|c|c|c|}
\hline Characteristics & Flashgame & Evolugame & Creagame & Jemulex & MOP \\
\hline Revenue in 2008 & 1.05 M€ & $2 \mathrm{M} €$ & $64 \mathrm{M€}$ & $1.6 \mathrm{M} €$ & $1.5 \mathrm{M} €$ \\
\hline Size (employees) & 17 & 40 & 500 & 12 & 24 \\
\hline $\begin{array}{l}\text { Internal resources } \\
\text { and skills held by } \\
\text { the developer }\end{array}$ & Productive & $\begin{array}{l}\text { Financial (low) } \\
\text { and productive }\end{array}$ & $\begin{array}{l}\text { Financial (high) } \\
\text { and productive }\end{array}$ & $\begin{array}{c}\text { Financial } \\
\text { (average), } \\
\text { technological, } \\
\text { and productive }\end{array}$ & $\begin{array}{l}\text { Financial (high), } \\
\text { technological, } \\
\text { and productive }\end{array}$ \\
\hline $\begin{array}{c}\text { Retained } \\
\text { intellectual } \\
\text { property rights }\end{array}$ & No & No & Yes & Yes & Yes \\
\hline Value captured ${ }^{11}$ & $5 \%$ of royalties & $13 \%$ of royalties & $100 \%$ of revenue & $50 \%$ of royalties & $60 \%$ of royalties \\
\hline $\begin{array}{l}\text { Relationships } \\
\text { within industrial } \\
\text { sector }\end{array}$ & $\begin{array}{l}\text { Manufacturers } \\
\text { and publishers }\end{array}$ & $\begin{array}{l}\text { Manufacturers } \\
\text { and publishers }\end{array}$ & $\begin{array}{l}\text { Manufacturers, } \\
\text { publishers, and } \\
\text { distributors }\end{array}$ & Distributors & Manufacturers \\
\hline $\begin{array}{l}\text { Nature of } \\
\text { technology }\end{array}$ & Mobile consoles & Home consoles & $\begin{array}{l}\text { Consoles (all } \\
\text { types) and } \\
\text { computer } \\
\end{array}$ & Computer & $\begin{array}{l}\text { Internet on } \\
\text { consoles }\end{array}$ \\
\hline Level of resource & ld by the devel & $r:$ low $: \leq 30 \%$ & \multicolumn{2}{|c|}{ average : between $31 \%$ and $50 \%$} & high $: \geq 51 \%$ \\
\hline
\end{tabular}

Table 2

Primary and Secondary Data Collected about SME Developers

\begin{tabular}{|c|c|c|c|c|c|c|}
\hline \multicolumn{2}{|r|}{ Data collected } & Flashgame & Evolugame & Creagame & Jemulex & MOP \\
\hline \multirow{3}{*}{ : } & $\begin{array}{l}\text { Number of } \\
\text { interviews }\end{array}$ & 3 & 3 & 5 & 3 & 4 \\
\hline & $\begin{array}{l}\text { Average time per } \\
\text { interview (hours) }\end{array}$ & $1: 26$ & $1: 23$ & 1:07 & $1: 14$ & $1: 37$ \\
\hline & Interviewees & $\begin{array}{l}\text { - Business } \\
\text { manager (1) } \\
\text { - Team manager } \\
\text { (2) }\end{array}$ & $\begin{array}{l}\text { - Technical } \\
\text { director (1) } \\
\text { - Artistic } \\
\text { manager (2) }\end{array}$ & $\begin{array}{l}\text { - IP manager (2) } \\
\text { - R\&D manager } \\
\text { (3) }\end{array}$ & $\begin{array}{l}\text { - Director (1) } \\
\text { - Technical } \\
\text { manager (2) }\end{array}$ & $\begin{array}{l}\text { - Creative } \\
\text { director (2) } \\
\text { - Project } \\
\text { manager (2) }\end{array}$ \\
\hline \multirow{2}{*}{ 苞 } & Internal data & $\begin{array}{c}\text { Prototyping } \\
\text { documents (2), } \\
\text { project } \\
\text { specifications (3) } \\
\end{array}$ & $\begin{array}{l}\text { Project } \\
\text { documentation } \\
\text { (5), emails (14) }\end{array}$ & $\begin{array}{l}\text { Contracts with } \\
\text { publishers (8), } \\
\text { project files (4), } \\
\text { emails (11) }\end{array}$ & $\begin{array}{l}\text { Statistics } \\
\text { reports (16), } \\
\text { emails (3) }\end{array}$ & $\begin{array}{l}\text { Meeting } \\
\text { reports (5), } \\
\text { emails (8) }\end{array}$ \\
\hline & External data & $\begin{array}{l}\text { Website, digital } \\
\text { journal articles } \\
\text { (3) }\end{array}$ & $\begin{array}{l}\text { Website, digital } \\
\text { journal articles } \\
\text { (4) }\end{array}$ & $\begin{array}{l}\text { Website (2), } \\
\text { digital journal } \\
\text { articles (14) }\end{array}$ & $\begin{array}{l}\text { Website, } \\
\text { digital journal } \\
\text { articles (7) }\end{array}$ & $\begin{array}{l}\text { Website, } \\
\text { digital journal } \\
\text { articles (4) }\end{array}$ \\
\hline
\end{tabular}

11 Percent of captured economic returns (royalties). In the video game industry, the logic of royalties depends of the budget advance makes by the publisher. As long as advance has not been repaid, the developers receives no royalties. 
Table 3: Data Coding Examples

\begin{tabular}{|c|c|c|c|c|c|c|c|c|c|c|c|c|}
\hline \multirow[b]{2}{*}{ 崩 } & \multirow[b]{2}{*}{ Comment } & \multicolumn{8}{|c|}{ Sources of dependence } & \multicolumn{3}{|c|}{$\begin{array}{c}\text { Strategic } \\
\text { choice }\end{array}$} \\
\hline & & 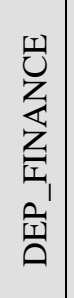 & 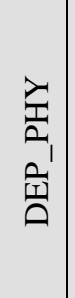 & 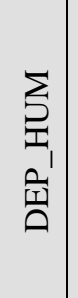 & 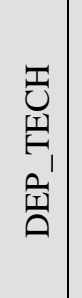 & 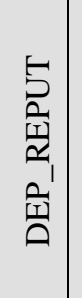 & 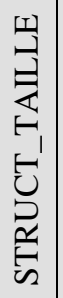 & 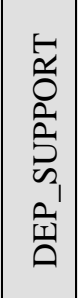 & 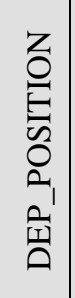 & 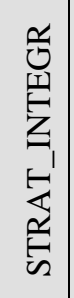 & 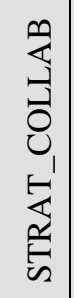 & 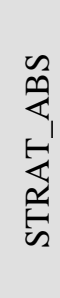 \\
\hline 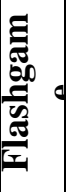 & $\begin{array}{l}\text { "Collaboration was also a way for us to build our } \\
\text { reputation. Maintaining rights related to our } \\
\text { creation, we become visible and we are building } \\
\text { a property portfolio" (Commercial director) }\end{array}$ & & & & & +++ & & & & & $\mathbf{x}$ & \\
\hline 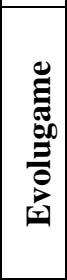 & $\begin{array}{l}\text { "Our reputation in the community is important to } \\
\text { us, even if it is not very important today, it is still } \\
\text { our calling card, it picks up more projects and } \\
\text { makes us more confident; but it does not mean } \\
\text { we can do whatever we want with our partners" } \\
\text { (Technical director) }\end{array}$ & & & & & ++ & & & & & $\mathbf{x}$ & \\
\hline 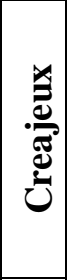 & $\begin{array}{l}\text { "Since that time we have gained a very good } \\
\text { reputation, thanks to our properties and licensing } \\
\text { success. That is why we have continued in that } \\
\text { voice. Today we continue to hire people to renew } \\
\text { our designs, our know-how, it's really our } \\
\text { philosophy" (IP manager) }\end{array}$ & & & & & $\varnothing$ & & & & $\mathrm{X}$ & & \\
\hline & $\begin{array}{l}\text { "Our small size is not a handicap, we want to } \\
\text { remain small to be flexible and not accountable } \\
\text { to anybody except distributors" (Head director) }\end{array}$ & & & & & & $\varnothing$ & & & & & \\
\hline$\stackrel{0}{\stackrel{0}{\rho}}$ & $\begin{array}{l}\text { "We still have problems with the online platform } \\
\text { consoles.... We had to constantly update the files } \\
\text { or even change some algorithms of the game due } \\
\text { to technological changes or debug patches } \\
\text { installed by manufacturers. It was really } \\
\text { compelling" (Creative director) }\end{array}$ & & & & & & & +++ & & & & \\
\hline
\end{tabular}




\section{Table 4}

\section{Main Sources of Dependence of Creative SMEs}

\begin{tabular}{|c|c|c|c|}
\hline & & Not a Source of Dependence if ... & Source of Dependence if ... \\
\hline \multirow{4}{*}{ 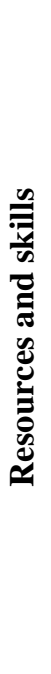 } & Financial & $\begin{array}{l}\text { The developer has sufficient financial } \\
\text { resources to manage the entire production and } \\
\text { distribution Process (MOP) }\end{array}$ & $\begin{array}{l}\text { The developer lacks sufficient financial resources } \\
\text { to undertake all its business processes (Flashgame, } \\
\text { Evolugame, Creagame, Jemulex). }\end{array}$ \\
\hline & $\begin{array}{l}\text { Technical } \\
\text { (IPR) }\end{array}$ & $\begin{array}{l}\text { The developer funds and develops its game } \\
\text { and thus retains full IPR (MOP, Jemulex). }\end{array}$ & $\begin{array}{c}\text { The developer transfers some or all its IPR to } \\
\text { outsiders to develop its game (Flashgame, } \\
\text { Evolugame, Creagame). }\end{array}$ \\
\hline & Reputation & $\begin{array}{c}\text { The developers has already an artistic } \\
\text { credibility in the sector and is recognized by } \\
\text { other actors an artistic and innovative } \\
\text { developer. This reputation provide a } \\
\text { bargaining power (Creagame, Jemulex, MOP) }\end{array}$ & $\begin{array}{l}\text { The developers has no or very low credibility } \\
\text { about its artistic expertise and its innovation } \\
\text { capacity. With this absence of reputation, the } \\
\text { developer has no or less bargaining power with } \\
\text { publishers (Flashgame, Evolugame). }\end{array}$ \\
\hline & Size & $\begin{array}{l}\text { The developer has a large size and has } \\
\text { sufficient resources to be fully or partially } \\
\text { autonomous on certain activities of the } \\
\text { innovation process (Creagame, MOP) }\end{array}$ & $\begin{array}{c}\text { The developer has a small size with few resources } \\
\text { that forces it to work with other actors to access } \\
\text { missing critical resources (Flashgame, } \\
\text { Evolugame, Jemulex) }\end{array}$ \\
\hline \multicolumn{2}{|c|}{$\begin{array}{l}\text { Nature of } \\
\text { technology } \\
\text { (support) }\end{array}$} & $\begin{array}{c}\text { Support and technical standards are not } \\
\text { imposed by manufacturers (Jemulex, } \\
\text { Creagame). }\end{array}$ & $\begin{array}{c}\text { Support and technical standards are provided by } \\
\text { console manufacturers (Flashgame, Evolugame, } \\
\text { Creagame, MOP). }\end{array}$ \\
\hline \multicolumn{2}{|c|}{$\begin{array}{l}\text { Position in } \\
\text { industrial sector }\end{array}$} & $\begin{array}{c}\text { The developer controls all activities in its } \\
\text { industrial sector or takes a position in a } \\
\text { market in which other major firms are absent, } \\
\text { such as the Internet (but not Internet services } \\
\text { on consoles). }\end{array}$ & $\begin{array}{l}\text { The developer does not control activities in its } \\
\text { industrial sector. Depending on its position, it may } \\
\text { be subject to downstream dependency (Jemulex) } \\
\text { or upstream dependency (MOP) or both } \\
\text { (Flashgame, Evolugame, Creagame). }\end{array}$ \\
\hline
\end{tabular}

Table 5

Sources of Dependence and Influences on Strategic Choices to Innovate

\begin{tabular}{|c|c|c|c|c|c|c|}
\hline & \multicolumn{5}{|c|}{ Sources of Dependence } & \multirow{3}{*}{$\begin{array}{c}\text { Strategies Implemented } \\
\text { by Developers to } \\
\text { Innovate }\end{array}$} \\
\hline & \multicolumn{3}{|c|}{ Resources and Skills } & \multirow{2}{*}{ Technology } & \multirow{2}{*}{ Position } & \\
\hline & Financial & $\begin{array}{l}\text { Transfer of } \\
\text { IPR }\end{array}$ & $\begin{array}{l}\text { Lack of } \\
\text { reputation }\end{array}$ & & & \\
\hline Flashgame & +++ & +++ & +++ & +++ & +++ & Unequal cooperation \\
\hline Evolugame & ++ & +++ & ++ & +++ & +++ & Egalitarian cooperation \\
\hline Creagame & ++ & $\varnothing$ & $\varnothing$ & +++ & ++ & $\begin{array}{l}\text { Integration of upstream } \\
\text { (diversification support) }\end{array}$ \\
\hline Jemulex & + & $\varnothing$ & $\varnothing$ & $\varnothing$ & + & $\begin{array}{c}\text { Integration of } \\
\text { downstream } \\
\text { (distribution integration) }\end{array}$ \\
\hline MOP & $\varnothing$ & $\varnothing$ & $\varnothing$ & +++ & + & Integration of upstream \\
\hline
\end{tabular}

Key: +++/++/+: Degrees of dependence of the developer; Ø: has no influence 


\section{References}

Adams, J.H., F.M. Khoja, and R. Kauffman (2012). "An empirical study of buyer-supplier relationships within small business organizations", Journal of Small Business Management, 50(1), 20-40.

Bahli, B., and S. Rivard (2003). "The information technology outsourcing risk: a transaction cost and agency theory-based perspective", Journal of Information Technology, 18, 211221.

Balakrishnan, S., and M.P. Koza (1993). "Information asymmetry, adverse selection, and joint ventures", Journal of Economic Behavior and Organization, 20, 99-117.

Barney, J. (1991). "Firm resources and sustained competitive advantage", Journal of Management, 17 (1), 99-120.

Baumol, W. (2002). The Free-Market Innovation Machine: Analyzing the Growth Miracle of Capitalism. Princeton, NJ: Princeton University Press.

Bowman, C., and V. Ambrosini (2000). "Value creation versus value capture: towards a coherent definition of value in strategy", British Journal of Management, 11, 1-15.

Burt, S.L., and L. Sparks (2003). "Power and competition in the UK retail grocery market", British Journal of Management, 14, 237-254.

Busija, E.C., H.M. O’Neill, and C.P. Zeithaml (1997). "Diversification strategy, entry mode, and performance: evidence of choice and constraints", Strategic Management Journal, 18 (4), 321-327.

Casciaro, T., and M.J. Piskorski (2005). "Power imbalance, mutual dependence, and constraint absorption: a closer look at resource dependence theory", Administrative Science Quarterly, 50, 167-199.

Chatterjee, D., and T. Ravichandran (2013). "Governance of interorganizational information systems: a resource dependence perspective", Information Systems Research, 24(2), 261278.

Chatterjee, S., and B. Wernerfelt (1991). "The link between resources and type of diversification: theory and evidence", Strategic Management Journal, 12 (1), 33-48.

Chesbrough, H. (2003). Open Innovation: The New Imperative for Creating and Profiting from Technology. Boston, MA: Harvard Business School Press.

Chesbrough, H., W. Vanhaverbeke, and J. West (2006). Open Innovation: Researching a New Paradigm. Oxford: Oxford University Press.

Chollet, B., M. Géraudel, and C. Mothe (2014). "Generating business referrals for SMEs: the contingent value of CEOs' social capital”, Journal of Small Business Management, 52(1), 79-101.

Cohendet, P., and L. Simon (2007). "Playing across the playground: paradoxes of knowledge creation in the videogame firm", Journal of Organizational Behavior, 28 (5), 587-605.

Davis, G.F., and J.A. Cobb (2010). "Resource dependence theory: past and future", Research in the Sociology of Organizations, 28, 21-42.

Davis, J. P., and K.M. Eisenhardt (2011). "Rotating leadership and collaborative innovation recombination processes in symbiotic relationships", Administrative Science Quarterly, 56(2), 159-201.

Diez-Vial, I. (2009). "Firm size effects on vertical boundaries", Journal of Small Business Management, 47(2), 137-153.

Drees, J.M., and P.P.M.A.R. Heugens, (2013). "Synthesizing and extending resource dependence theory: a meta-analysis", Journal of Management, 39(6), 1666-1698.

Dunford, R. (1987). "The suppression of technology as a strategy for controlling resource dependence", Administrative Science Quarterly, 32(4), 512-525.

Emerson, R.M. (1962). "Power-dependence relations", American Sociological Review, 27 (1), 31-41. 
Eppinger, E., and G. Vladova (2013). "Intellectual property management practices at small and medium-sized enterprises", International Journal of Technology Management, 61 (1), 64-81.

Fink, M., and A. Keesler (2010). "Cooperation, trust and performance-empirical results from three countries", British Journal of Management, 21, 469-483.

Finklestein, S. (1997). "Interindustry merger patterns and resource dependence: a replication of Pfeffer (1972)", Strategic Management Journal, 18(10), 787-810.

Gaffney, N., B. Kedia, and J. Clampit (2013). “A resource dependence perspective of EMNE FDI strategy”, International Business Review, 22(6), 1092-1100.

Gardet E., and S. Fraiha (2012). "Coordination modes established by the hub firm of an innovation network: the case of a SME bearer", Journal of Small Business Management, 50(2), 216-238.

Gardet, E., and C. Mothe (2011). "The dynamics of coordination in innovation networks", European Management Review, 8 (4), 213-229.

Greenman, A. (2012). "Entrepreneurial activities and occupational boundary work during venture creation and development in the cultural industries", International Small Business Journal, 30 (2), 115-137.

Gulati, R. (2007). Managing Network Resources: Alliances, Affiliations, and Other Relational Assets, Oxford University Press, Oxford UK.

Gulati, R., and M. Stych (2007). "Dependence asymmetry and joint dependence in interorganizational relationships: effects of embeddedness on a manufacturer's performance in procurement relationships", Administrative Science Quarterly, 52, 32-69.

Gulati, R., F. Wohlgezogen, and P. Zhelyazkov (2012). "The two facets of collaboration: cooperation and coordination”, Strategic Alliances Academy of Management Annals, 6(1), 531-583.

Hagedoorn, J. (1993). "Understanding the rationale of strategic technology partnering. interorganizational modes of cooperation and sectoral differences", Strategic Management Journal, 14 (3), 371-385.

Hall, R. (1992). "The strategic analysis of intangible resources", Strategic Management Journal, 13 (2), 135-144.

Hall, R. (1993). "A framework linking intangible resources and capabilities to sustainable competitive advantage", Strategic Management Journal, 14, 607-618.

Hallen, B.L., and K.M. Eisenhardt (2012). "Catalyzing strategies and efficient tie formation: How entrepreneurial firms obtain investment ties", Academy of Management Journal, 55: 35-70

Hamel, G., Y.L. Doz, and C.K. Prahalad (1989). "Collaborate with your competitor and win", Harvard Business Review, 67 (1), 133-139.

Hamel, G., and C.K. Prahalad (1994). Competing for the Future. Boston, MA: Harvard Business School Press.

Hillman, A.C. (2005). "Politicians on the board: do connections affect the bottom line?", Journal of Management, 31, 464-481.

Hillman, A., C. Shropshire, and A. Cannella, (2007). "Organizational predictors of women on corporate boards", Academy of Management Journal, 50, 941-952.

Johns, J. (2006). "Video games production networks: value capture, power relations and embeddedness", Journal of Economic Geography, 6 (2), 151-180.

Katila, R., J. Rosenberger, and K. Eisenhardt (2008). "Swimming with sharks: technology ventures, defense mechanisms and corporate relationships", Administrative Science Quarterly, 53, 295-332.

Kumar, K., and H.G. Van Dissel (1996). "Sustainable collaboration: managing conflict and cooperation in interorganizational systems", MIS Quarterly, 20 (3), 279-300. 
Lavie, D. (2006). "The competitive advantage of interconnected firms: an extension of the resource-based view", Academy of Management Review, 31 (3), 638-658.

Lepak, D.P., K.G. Smith, and M.S. Taylor (2007). "Value creation and value capture: a multilevel perspective", Academy of Management Review, 32 (1), 180-194.

Miles, M.B., and M. Huberman (2003). Analyse des Données Qualitatives, 2d ed., Paris: De Boeck.

Miles, G., S.B. Preece, and M.C. Baetz (1999). "Dangers of dependence: the impact of strategic alliance use by small technology-based firms", Journal of Small Business Management, 37 (2), 20-29.

Mohr, J., and R. Spekman (1994). "Characteristics of partnership success: partnership attributes, communication behavior, and conflict resolution techniques", Strategic Management Journal, 15 (2), 135-152.

Nienhüser, W. (2008), "Resource dependence theory: how well does it explain behavior of organizations?", Management Revue, 19, 9-32.

Nooteboom, B., G. De Jong, R.W. Vossen, S. Helper, and M. Sako (2000). "Network interactions and mutual dependence: a test in the car industry", Industry and Innovation, 7 (1), 117-144.

Oliver, C. (1990). "Determinants of interorganizational relationships: integration and future directions", Academy of Management Review, 15 (2), 241-265.

Ozcan, P. and K.M. Eisenhardt (2009). "Origin of portfolios: entrepreneurial firms and strategic action", Academy of Management Journal, 52, 246-279.

Pfeffer, J., and G. Salancik (1978). The External Control of Organizations. A Resource Dependence Perspective. New York: Harper \& Row.

Pisano, G.P., and D.F. Teece (2007). "How to capture value from innovation: shaping intellectual property and industry architecture", California Management Review, 50 (1), 278-296.

Rhee, M., and M.E. Valdez (2009). "Contextual firms surrounding reputation damage with potential implications for reputation repair", Academy of Management Review, 34 (1), 146-168.

Rindfleisch, A., A.J. Malter, S. Ganesan, and C. Moorman (2008). "Cross-sectional versus longitudinal survey research: concepts, findings, and guidelines”, Journal of Marketing Research, 45, 261-79.

Shuang-yan, L., Z. De-zhi, and J. Fang-ping (2013). "Base inventory cooperation strategy of multi-parts with supply-hub”, International Journal of Business and Management, 8(2), 96-104.

Stieglitz, N., and K. Heine (2007). "Innovations and the role of complementarities in a strategic theory of the firm", Strategic Management Journal, 28, 1-15.

Storz, C. (2008). "Dynamics in innovation systems: evidence from Japan's game software industry", Research Policy, 37 (9), 1480-1491.

Tan, J., W. Zhang, and J. Xia (2008). "Managing risk in a transitional environment: an exploratory study of control and incentive mechanisms of venture capital firms in China", Journal of Small Business Management, 46 (2), 263-285.

Teece, D.J. (1982). "Towards an economic theory of the multiproduct firm", Journal of Economic Behavior and Organization, 3, 39-63.

Teece, D.J. (1986). "Profiting from technological innovation", Research Policy, 15 (6), 285305.

Timmer, J., M. Chessa, and R.J. Boucherie (2013). "Cooperation and game-theoretic cost allocation in stochastic inventory models with continuous review”, European Journal of Operational Research, 231(3), 567-576. 
Tschang, F.T. (2007). "Balancing the tensions between rationalization and creativity in the video games industry", Organization Science, 18(6), 989-1005.

Villalonga, B., and A.M. McGahan (2005). "The choice among acquisitions, alliances and divestitures", Strategic Management Journal, 26 (13), 1183-1208.

Voss, U. and M. Brettle (2013). "The effectiveness of management control in small firms: perspectives from resource dependence theory", Journal of Small Business Management, published online, 6 August 2013.

Vossen, R.W. (1998). "Relative strengths and weaknesses of small firms in innovation", International Small Business Journal, 16 (3), 88-95.

Wang, L., and E. Zajac (2007). "Alliance or acquisition? A dyadic perspective on interfirm resource combinations", Strategic Management Journal, 28 (13), 1291-1317.

Westphal, J.D., S. Boivie, and D.H.M. Chang (2006). "The strategic impetus for social network ties: reconstituting broken CEO friendship ties", Strategic Management Journal, 27, 425-445.

Wolff, J. and T. Pett (2006). "Small firm performance: modeling the role of product and process improvements", Journal of Small Business Management, 44, 268-284.

Wright, P.M., G.C. McMahan, and A. McWilliams (1993). "Human resources and sustained competitive advantage: a resource-based perspective", International Journal of Human Resource Management, 5 (2), 301-326.

Wry, T., J.A. Wobb, and H.E. Aldrich (2013). "More than a metaphor: assessing the historical legacy of resource dependence and its contemporary promise as a theory of environmental complexity", Academy of Management Annals, 7(1), 441-488.

Xia, J., and S. Li (2013). "The divestiture of acquired subunits: a resource dependence approach", Strategic Management Journal, 34, 131-148.

Yin, R. (1994). Case study research: Design and methods, 2d ed. Beverly Hills, CA: Sage Publications.

Zhang, H., C. Shu, X. Jiang, and A.J. Malter (2010). "Managing knowledge for innovation: the role of cooperation, competition, and alliance nationality", Journal of International Marketing, 18(4), 74-94. 